\title{
CIÊNCIA'NATURA
}

\section{WATER GOVERNANCE: ASSUMPTIONS TO ASSIGN A NEW MEANING TO IT}

\author{
Luciana Turatti e Jane Márcia Mazzarino \\ Centro Universitário Univates. Lajeado, RS, Brasil
}

\begin{abstract}
Taking into consideration the current scenario of access to water resources and their significance for human survival, as well as the fact they have become a human right, it can be said that public policies of governance in this aspect need to go beyond their traditional format to effectively encompass participatory processes. Environmental public policies have shown not to satisfactorily respond to the challenges posed, which is partly due to the governance models employed. Studies on governance processes in the Brazilian context have indicated that, despite the alleged inclusiveness in the public policies processes, these transformative ideals have not been attained yet. This study aims at establishing theoretical assumptions on the concept of governance, so as to find elements to assign a new meaning to it, once it has been overused, with a subsequent loss of its signification, in order to contribute to studies on water governance in the scope of hydrographic basins. The method used is qualitative and bibliographic.
\end{abstract}

Keywords: Governance. Water resources. New meaning. Bibliographic method

\section{RESUMO}

Levando em consideração o cenário atual de acesso aos recursos hídricos e a sua importância para a sobrevivência humana, bem como o fato de que trata-se de um direito humano, pode-se dizer que as políticas públicas de governo neste aspecto precisam ir além do seu formato tradicional para eficazmente abranger processos participativos. Políticas públicas ambientais têm demonstrado não responder satisfatoriamente aos desafios colocados o que, em parte, deve-se aos modelos de governança empregados. Os estudos sobre os processos de governança no contexto brasileiro têm indicado que, apesar da alegada inclusão em processos de políticas públicas, esses ideais de transformação ainda não foram atingidos. Este estudo visa estabelecer pressupostos teóricos sobre o conceito de governança, de modo a encontrar elementos para atribuir um novo significado para ele, uma vez que foi usado em demasia, com uma subsequente perda de sua significação, a fim de contribuir para os estudos sobre a governação da água em o âmbito de bacias hidrográficas. O método utilizado é qualitativo e bibliográfico.

Palavras-chave: Recursos hídricos. Governança. Ressignificação. Método bibliográfico 


\section{Introduction}

This study is based on the assumption that a potential shortage of potable water is a result of a governance crisis rather than of a water crisis. The causes usually said to trigger the so called water crisis, namely countries' geographic position, pollution, increased world population, wastage, and high consumption by means of production, food production, among others, challenge States to promote public policies of governance. These, on the other hand, have shown not to satisfactorily respond to the challenges posed, what is related to the governance models employed.

Studies suggest that one of the major challenges in governance processes has been the full participation of all social groups involved in environmental issues. In other words, they have been neither inclusive nor cooperative, and therefore do not promote a real social transformation. On the other hand, Boaventura de Souza Santos proposes the concept of an insurgent counter-hegemonic governance, referring to a variety of social movements and organizations of the civil society, articulated to combine strategies and tactics that lead to the planning of collective actions. This form of action has been seen in several social global manifestations, but not in those regarding the water issue, thus justifying the discussion in this study.

The purpose of this study is to establish theoretical assumptions on the concept of governance, so as to find elements to assign a new meaning to it, once it has been overused, with a subsequent loss of signification, in order to contribute to studies on water governance in the scope of hydrographic basins. The method used is qualitative and bibliographic.

\section{Water as a human right}

This study assumes the right to access water as a right inherent to the human condition. In this aspect we agree with Jonas (2011, page 229), who claims that 'we, human beings, as products coming from nature, have to be loyal to all creations we have connections with, and as our own being is in its highest rank, we shall take care of all others'.

The emergence of water as a natural right is originated from historical conditions, from basic needs or from notions of justice, according to Shiva (2006). The right to water as a natural right is not originated in the State, once the human existence has an ecological character. People have the right to life and to the resources that support life. Life's need for water is the reason why the right to water has been accepted as a natural and social fact, the author points out. As it happens with the natural rights, the right to water is a usufructuary right, that is, water may be used, but not owned.

As water is part of the environment, considered as essential to preserve life, it also integrates the concept of human right; this justifies the needed concerns with this resource, especially within contexts in which access to water is not a privilege to all.

Acknowledging water as a fundamental human right is expressed in several international documents, a result of events such as the United Nations Conference on Water in 1977, held in Mar Del Plata; the International Conference of Water and the Environment, in 1992 in Dublin; United Nations Conference on Environment and Development, Rio 92 or ECO 92, held in Rio de Janeiro in 1992; and United Nations Millennium Declaration, in 2000 in New York.

According to a more thorough interpretation, it could be even said that the Declaration of the United Nations Organization in 1948 already mentioned this right indirectly, when it acknowledged the right to life, once water is closely related to the maintenance of the human species. Perhaps this right was not approached directly then because at that time one could not imagine that water would become scarce for millions of people around the world, and that it would be necessary to manifest its importance through an international document, as a means to guarantee access to it.

Nevertheless, even if one admits that the access to water is vital to human beings, and consequently, vital to a dignified life, it is indispensable to assure the management of this resource based on society's general interest and active participation, as well as to fully acknowledge such right in the legal system in force, besides guaranteeing that the Public Power shall be liable for its defense and protection (García 2008). In Brazil, the National Policy for Water Resources, known as the Law of Water, provides these guarantees and created the Hydrographic Basin Committees.

The committees establish a democratic scope for managing water, emerging as one of the loci with the greatest potential to promote processes of water governance. This happens because the Hydrographic Basin Committees are composed by representatives of public management, by water users and by civil entities of water resources with proven participation in the basin issues. The number of representatives of each sector and the criteria for their selection are set by each committee. According to Article 37 of the Law of Water, the Hydrographic Basin Committees action range is the total area of a hydrographic basin, which is outlined by the geography of the water in a certain territory. The Hydrographic Basin Committees are in charge of promoting debates on water resources among the entities that compose them, as well as settling conflicts, approving and monitoring the execution of the Plan for Water Resources in the basin, making proposals to the National and State Councils for Water Resources on granting rights to use the water resources, as well as establishing mechanisms and suggesting values to be charged for the use of water resources (BRASIL, 1997).

Nevertheless, against an equitable and sustainable management of water are the interests of the big world capitals that decisively influence States and international organizations - specifically the financial and credit organs - to obtain water regulations that meet their hegemonic interests. In other words, the ecologic approach and the guarantee of managing and regulating water 
faces persistent and fierce opposition from the big transnational corporations, to which exploration of this resource represents a highly profitable business.

Within this context, and considering the current water crisis, it is necessary for governments to take their role in controlling and managing water resources, by applying the concepts of sustainability and equity to water policies, otherwise the privatizations might reach such a point that it may become impossible for the Public Power to intervene in the distribution of this asset, considered as common and fundamental. The main justification of the transnational corporations for privatizing water is based on the inefficiency and lack of competence of the public sector to manage water resources.

According to Garcia (2008), studies of Brazilian cases published by Barlow and Clarque show that the public water companies are able to operate efficiently. The first one refers to a case in São Paulo, where in 1995 the water public service (SABESP) started a major restructuring to operate in a more modern and efficient manner. In this process, SABESP was able to increase the income generated, as well as to reduce operational costs by $45 \%$. Another successful example is the water management in Porto Alegre, based on mixed economic partnership model, where popular movements were able to establish a public-communitarian management of water. Garcia mentions Viero, who states that in this case the public water service showed not only to be feasible from a financial viewpoint, but also extended the service to a bigger share of the population. The Municipal Department for Water and Sewage System (DMAE) currently supplies to 99\% of the population, with one of the lowest rates in the country. This successful management is due, partly, to the service rendering guidelines: population's basic needs cannot become a source of private profit and, as essential services are strategic to the nation, they must be managed according to the population's will.

In summary, Garcia (2008) claims that water must be democratically managed by the public powers, once it is much more than a production factor. Water is an ecological, economic and social asset, part of a country's wealth, and preserver of life.

Ruiz (2007) supports the application of the shared responsibility principle, by reviewing the relationships among public environmental managers and citizens, so as to achieve a participatory management of these assets, as a key to the new dimension of preventive environmental protection. Such principle represents a guideline that establishes the functioning of a policy focusing on meeting targets regarding sustainable development and participation principle.

Besides adopting the shared responsibility as a guideline to manage water resources, the Public Power is in charge of defining the necessary minimum conditions to put the right to water into practice, which presupposes the access to this resource.

Regarding this right, UNO's General Comment no. 15 (Committee on Economic, Social and Cultural Rights UN, 2002) approved in November 2002 in Geneva by the Committee on Economic, Social and Cultural Rights, states that the right to water is a prerequisite for the realization of other human rights, once it is indispensable for a dignified life. This document also claims that the State shall:

a) guarantee the access to a minimum essential amount of water, enough and suitable for personal and domestic use, and to prevent illnesses (human consumption, health, hygiene and food preparation);

b) guarantee the access to water, facilities and services, without discrimination, especially regarding more vulnerable groups;

c) guarantee physical access to facilities;

d) assure that services provide sufficient and regular supply of potable water;

e) avoid personal security to be threatened when the population needs to obtain water;

f) guarantee an equitable distribution of available water facilities and services;

g) adopt and regularly review, through a participatory and transparent process, a national strategy and action plan regarding water, that includes indicators and references to assess progress achieved, paying special attention to marginalized groups;

h) assure that the quality of the water supplied meets the minimum requirements to guarantee people's health and environment protection, and also that both communities' needs and cultural practices are taken into consideration.

Recently some specialized international organs reaffirmed a concrete content regarding the obligation to guarantee this right to all individuals, by establishing a minimum amount of water. According to the World Health Organization (WHO) and UNI$\mathrm{CEF}$, twenty liters of water per day is a sufficient amount for an individual to drink and to use in basic personal hygiene, this without including the water necessary for bathing, in which case the minimum amount would reach fifty liters (Garcia 2008).

Furthermore, according to UNO's General Comment no. 15/2002, the right to water imposes three kinds of obligations on the State:

a) to respect or refrain from interfering with the enjoyment of the right to water, from engaging in any activity that limits equal access to water, from arbitrarily interfering in the traditional systems of water allocation, and from contaminating the water.

b) to protect or prevent third parties (individuals, groups, corporations and other entities) from interfering with the enjoyment of the right to water; to adopt necessary measures to restrain third parties from denying equal access to adequate water, from contaminating or inequitably extracting from water resources.

c) to fulfil, which encompasses to facilitate (to take measures to assist individuals and communities to enjoy the right), promote (provide appropriate education concerning the hygienic use of water and methods to minimize water wastage) and provide (fulfil the right when individuals or a group are unable to realize that right themselves) the access to adequate water.

In short, the existence of millions of people in the world without access to potable water nowadays cannot be understood as a mere trouble or fortuity. Such scenario is an imperative for a new culture regarding human relationship with water resources. 
As a human right threatened by economic interests of transnational corporations, and with the successful examples of community public management, and also considering the need for the public managers to guarantee quantity and quality access to this resource, it is imperative the construction of processes of water governance.

Within this context, two questions emerge: what dimensions are included in the concept of governance, widely mentioned and many times with its signification emptied through its use by players of various social fields? How can we assign a new meaning to this concept, to appropriate it and to reflect it on water governance?

\section{Theoretical assumptions for a multidimensional governance model}

Governance has been accepted as the global expression to face environmental problems. One such example was the inclusion of governance, along with the green economy, as the main agenda in the UN Conference for the Sustainable Development, Rio +20 , held in Rio de Janeiro in June 2012.

Fonseca and Bursztyn (2009) support that the criteria for governance have already been established worldwide. However, many of them are too general and do not take into account the specificities of the groups and contexts in which they are applied. The authors direct their criticism especially to a document called Guide to Good Governance, based on criteria used by the International Monetary Fund and the World Bank to assess and choose projects to be financed by these organizations. The authors consider that the general criteria, not compatible with the reality where they will be applied, favor trivialization and affect the efficiency of environmental and sustainable development policies. Therefore, they make a serious criticism on replicating environmental programs and projects without taking into account social, cultural, political, economic, and environmental specificities of the territories where they will be implemented, which determine their success or failure. They add, '[....] paradoxically, the reason for their success tends to be precisely the originality of these practices' (Fonseca and Bursztyn 2009, p. 23).

Based on Farland and Grindle, Fonseca and Bursztyn claim that governance is related to a comprehensive, efficient and fair political process, one that is also politically plural, based on the transparency of public decisions and including an array of players and processes, as a way to legitimately distribute power through rules and norms collectively established. It is a process of co-accountability among the various players regarding the theme at stake, which needs to address the common good, culminating in a process of democratized, decentralized and participatory management of public policies (Fonseca and Bursztyn 2009, page 23).

The implementation of governance processes out of cultural contexts is a historic matrix that is perpetuated, and it is related to the origin of the expression. According to a study by Boaventura de Souza Santos (2005), the governance models employed up to then were heavily influenced by neoliberal theories, and, therefore, they have promoted social exclusion and economic polarization, rather than a project of social inclusion and redistribution. As per Boaventura, since the mid-1990s, governance has become the political matrix of neoliberal globalization. Citing Habermas and Offe, Santos states that the crisis has come from the radical questioning on both the social and democratic content of the social contract underlying the social-democratic States after the end of the Second World War.

The questioning proposed by movements such as the students', ecologic and women's movement occurred because the social contract established then did not guarantee these movements in the discussions, thus even abandoning the ideals of democracy.

Unlike this, a report published by Crozier, Huntington and Watanuki, members of the so-called Trilateral Commission, indicated the existence of a crisis, not one of insufficient democracy, but one related to an overload of democracy. According to this report, the social contract established after the Second World War had overloaded the existing democracies with claims and rights (Santos 2005).

Therefore, instead of attributing such maladies to a legitimacy crisis, as desired by the social movements, the neoliberal forces created a governability crisis. As per Santos $(2005$, p. 12) ' [....] previously the focus had been the inability of the State to make justice to the new social movements and their claims, and now it has become the need to restrain and control the society claims towards the State', to which palliative alternatives were sought.

[....] instead of social transformation, problem resolution; instead of social participation, stakeholders' participation; instead of a social contract, self-regulation; instead of social justice, positive sum games and compensatory policies; instead of power relations, coordination and partnerships; instead of social conflict, social cohesion and flow stability. Therefore, rather than serving a project for social inclusion and social redistribution, they indeed serve social exclusion and economic polarization (Santos 2005, p. 14)

Fonseca and Bursztyn also connect the emergence of the expression governance to the dissemination of neoliberal ideas and practices along the last quarter of the 20th century, once they claim that this concept '[...] is connected to a wide process to diminish the State and to appreciate incorporating players from the outside of the state apparatus into political processes and public policy management'. 
Nevertheless, they support that

[...] its path gained an own life and acquired features that go far beyond the mere transference of regulatory responsibility from the government to the market. Features such as participation, decentralization, accountability and equity among the players provide the notion of governance with a content of legitimacy and pragmatism, opening space for a regulation that takes into consideration extra-economic factors. (Fonseca and Bursztyn 2009, p. 21).

Is it possible to detach the concept of governance from its strong connection to neoliberalism? Santos (2005, p. 22) believes that the emergence of a counter-hegemonic governance proposal is possible, one that opposes the neoliberal ideals, '[....] which implies in an articulation and coordination among a wide variety of social movements and civil society organizations, aiming at combining strategies and tactics, defining agendas, as well as planning and putting collective actions into practice'.

In order for this ideal to be attained and for the community participation in the decision-making process to increase, it is assumed that the correct environmental information has to be circulated, which is characterized as an element of social emancipation for individuals.

A real socio-political participation demands the bureaucratized forms of governance to be transformed, as for example, those which result from the application of guides, as criticized by Fonseca and Bursztyn (2009), generating what Jacobi (1999) characterizes as the formation of ties that bind social groups to other social groups, and social groups to social projects, which require them to establish a set of socially identified problems, objectives and solutions (Jacobi 1999, p. 43).

Jacobi $(2012$, p. 71) defines governance as '[....] the deliberate and continuous exercise to develop practices whose analytical focus lies on the notion of social power that pervades the relations among State, Civil Society and Market', where decision-makers and non decision-makers unite for a common goal. According to this author, governance processes require partnership, network action, empowerment, a perception of interdependence among players, integration, complementarity, co-accountability, educational practices, shared decision-making and negotiation. (Jacobi 2012)

This last one is one of the fundamental elements in governance processes, once it results from the perception of players with common objectives, but the distinct perceptions of these many times bring about conflicts, which require public communication processes to be adopted. (Jacobi 2012)

As Jacobi states, '[...] participation in managing public affairs, as a corrective to the limitations of representative democracy, enables, at least theoretically, the civil society to engage in designing public policies and in controlling governmental actions and public affairs' (Jacobi 1999, p. 38).

Notwithstanding, it is not enough to assure the expansion of participation channels, the engagement with the public affairs, and the layout of common ideals; one has to be aware that individuals might be manipulated by groups with special interests.

Within this context, Fonseca and Bursztyn (2009) call attention to the risk of decentralization bringing about the strengthening of local elites that exercise their power through clientelism and patrimonialism, further deviating the process from the public interest. Therefore, guaranteeing participation channels does not assure it will happen equally and efficiently, once restrains of several kinds (economic, social, political, cultural ones, even players reaching the places where decision-making processes occur, among others) may limit participation, favoring the strengthening of elites already established, thus reinforcing inequalities. The authors mention the cases of the municipal councils and hydrographic basin committees, in which establishing a bigger participation does not assure representativeness and expression of the distinct individuals or groups, which consequently keeps then difference between a politically active minority and a passive majority.

These models based on reproducing relations cannot be characterized as governance processes, once they neither transform nor enable the access to public debate in an equalitarian form, thus conserving a social reality rather than transforming it.

Therefore, it can be observed that the concept of governance, besides being a matrix of neoliberal globalization policy, is currently characterized essentially by its multidimensionality of meaning, and before the matrixes that mostly characterize the contemporary decision-making processes, it may become a model with a strong transforming, and sometimes even a revolutionary character. In order for this to happen, it is necessary to do away with the neoliberal culture features that determined its origin, assigning a new meaning to it by allowing the governance process to become effectively democratic, and a builder of citizenship.

\section{Assigning a new meaning to governance so as to construct water governance}

After having established the theoretical assumptions on the concept of governance, elements are shown to assign a new meaning to it, so as to contribute to the studies on water governance, which may especially contribute to the practice in the scope of hydrographic basin committees or of similar organizations.

Assigning the concept of governance a new meaning in order to construct processes of water governance requires not replicating models, but those involved in it to be open to the ongoing turmoil cultural processes in social groups. Likewise, it needs to be based on transparency, what requires players to have the courage to take their stance, facing conflicts inherent to 
social groups, possibly with the need of mediators, so that the process is not lost.

Consequently, new meanings to governance also presuppose that players engage in the objectives and interests at stake, and negotiation processes that take place, which implies in a commitment with an effective, and not a representative or bureaucratized, participation. Therefore, another fundamental element emerges to assign a new meaning to governance: the search for information that generates qualified participation in the public communication process, that gathers the demands from all society groups involved in the debate issues.

See below seven interrelated elements that contextualize the water issue as a starting point for the water governance processes:

a) acknowledging water as a fundamental human right through debate forums and international agreements has not been enough up to now to halt the exclusion of a significant part of the population who do not have access to water;

b) one may say that there is currently a world water crisis, but it is rather a crisis of governance than that of water scarcity, regarding access to water;

c) this crisis exists because the governance models employed up to now have been strongly influenced by neoliberal theories, many times promoting exclusion and economic polarization, rather than inclusion and social redistribution;

d) rather than participation of the State, Civil Society and Market, governance of environmental assets may be defined as a governance in which human society finds representation community spaces and loci, in which they may, voluntarily, establish cooperative and participatory forms of managing common goods or resources, considered shared natural assets;

e) constructing a strategic water governance process is a need, once a proposal for an equitable and sustainable water management currently opposes the interest of the major world capitals, that have decisively influenced States and international organizations;

f) the hydrographic basin committees, such as those organized in Brazil and other Latin American countries, or even in Europe, play an essential role in constructing a model for water governance, once they are in charge of assuring a democratic management of water resources;

g) implementing public governance policies that promote lasting economic, social and institutional development by balancing the power among the distinct social groups, and based on values such as social ethics, solidarity and sustainability, basic assumptions to make universal access to water a reality.

For water governance to be effective, one needs to take these elements, which go beyond boundaries, into account. Moreover, when the water issue is reflected upon, boundaries are blurred, whether they are of geographical, of political or of social nature. It is only natural, once it is inherent of waters to flow, pass through, overflow, and vanish, sometimes to emerge again with a fierce power.

The water metaphor may be used with the society movement, which many times is quiet and hidden, to emerge from time to time with a sudden power, inherent to it. As the water, global manifestations showing general dissatisfaction with the traditional political processes have exposed social currents, both deep and superficial.

Therefore, one is required to go beyond the notion of what is public and private, to seek for social control of what is considered as a public asset, belonging to all the people, as in the case of water. From it, access to participate in the public loci emerges, which is one of the elements of meaning of governance processes, and one of the most precious ones.

The environmental issue, mainly the water resources, is a theme that remains below the surface, in latency in the social agenda. Whenever it emerges as a process of public communication, the social asymmetries and distinct needs and uses become explicit; it is needed for production, culture, survival, management of the public asset, self-organization to claim power, similarly to the orchestration of social powers, so as to articulate distinct interests into common objectives for a strategic action on this universal good.

This strategic action has not been made effective by the hydrographic basin committees, they do not invest in communication processes among their members, and between the committees and the communities they belong to. If there are currently loci with the capacity of triggering water governance processes in Brazilian society, these are the hydrographic basin committees. Nevertheless, since they have been established recently, they still lack communicational and political maturity.

The committees can trigger processes of water governance through community spaces by shifting the meetings to several municipalities on days and times that favor citizens' participation, and appropriating their language to the cultural diversity of the public, so as to engage them in the debates, in a participatory way, thus engaging them in this very theme, that is public and vital.

Furthermore, it is essential to face power centralizations in these processes, established by the speech power in the public locus, which reveals inequalities of symbolical and material resources among players and groups.

Communities must be acknowledged in their specificities, and in turn, communities must acknowledge they need to make decisions aiming at the water welfare in their basin territory, by taking into account the diverse interests. Therefore, all need to mutually acknowledge their social needs and realities, which very often are not transparent. Eventually, the basin committees may become as a converging point not only for water, but also for the realities and needs experienced by the groups they gather.

The participatory processes have to be continuous and coordinate popular know-how so as not to perpetuate apathy, lack of interest and disbelief regarding social processes. Giaretta, Fernandes and Phillipi (2012, p. 542) have observed in their studies on participatory processes that public managers, many times act as private managers, by not considering their duty to 
share decisions and base them on social demands. 'On the other hand, the population does not see the public management as public, does not have a feeling of belonging, and thus is not interested in participating in it'.

Access to information is a requirement for participation, which in turn is an essential element to water governance. Within this context, the territory of the hydrographic basin is outlined as a strategic scope for an integrated analysis of the problems regarding water resources at diverse levels: local-regional-national-global.

Without information on the multiple dimensions of the water status in distinct geographical contexts, the inclusion of human beings as natural beings, not only political ones, cannot be assured, which reflects in assigning a new meaning to water governance.

Information and participation do not assure water governance by themselves, but are indispensable for it to have a chance to be constructed. Without knowledgeable participation there is no engagement and accountability in decision-making, which weakens the social power of debate forums and decision loci such as the basin committees.

\section{Bibliographic reference}

BRASIL. Lei no 9.433, de 8 de janeiro de 1997. Política Nacional de Recursos Hídricos. Available in: <http://www.planalto.gov. br/ccivil_03/LEIS/19433.htm>. Access in October 2013.

Committee on Economic, Social and Cultural Rights UN, 2002. Substantive issues arising in the implementation of the international covenant on economic, social and cultural. General Comment No. 15. The right to water (arts. 11 and 12 of the International Covenant on Economic, Social and Cultural Rights). Available in: <http://www.unhchr.ch/tbs/doc.nsf/0/ a5458d1d1bbd713fc1256cc400389e94/\$FILE/G0340229.pdf>. Access in October 2013.

FONSECA, I. F.; BURSZTYN, M. jan/apr 2009. A banalização da sustentabilidade: reflexões sobre governança ambiental em escala local. Sociedade e Estado. Brasília, v.24, n.1, p. 17-46. Available in <http://www.scielo.br/pdf/se/v24n1/a03v24n1> Access in October 2013.

GARCÍA, A. El derecho humano al água. Madrid: Editor+, 2008.

GIARETTA, J. B. Z.; FERNANDES, V.; PHILIPPI JR., A. jul/sep 2012. Desafios e condicionantes da participação social na gestão ambiental municipal no Brasil. Organizações \& Sociedade. Salvador, v.19, n.62, p. 527-550. Available in: <http://www. scielo.br/pdf/osoc/v19n62/09>. Access in December 2013.

JACOBI, P. R. jan/feb 1999. Poder local, políticas sociais e sustentabilidade. Saúde e Sociedade [online]. São Paulo, v.8, n.1, p. 31-48. Available in: <http://www.scielo.br/scielo.php?script=sci_arttext\&pid=S0104-12901999000100004>. Access in October 2013.

JACOBI, P. R. and Sinisgalli, P.A.A., jun (2012). Governança ambiental e economia verde. Ciência \& Saúde Coletiva [online]. Rio de Janeiro, v.17, n.6, p. 1469-1478. Available in: <http://www.scielo.br/pdf/csc/v17n6/v17n6a11.pdf >. Access in October 2013.

JONAS, H. O princípio da responsabilidade: ensaio de uma ética para civilização tecnológica. Tradução Marijane Lisboa, Luiz Barros Montez. Rio de Janeiro: Contraponto, 2011

RUIZ, M. M. La gestión ambiental compartida: función pública y mercado. Valladolid: Editora Lex Nova, 2007.

SANTOS, B. S. oct. A crítica da governação neoliberal: o Fórum Social Mundial como política e legalidade cosmopolita subalterna. Revista Crítica de Ciências Sociais, 72, 7-44, 2005.

SHIVA, V. Guerras por águas: privatização, poluição e lucro. São Paulo: Radical Livros, 2006.

Luciana Turatti
Centro Universitário Univates. Lajeado, RS, Brasil
Professora do Programa de Pós-Graduação Ambiente e Desenvolvimento,
Emai: lucianat@univates.br
Participação do autor: Todo o artigo foi realizados por ambas as partes.
Jane Márcia Mazzarino
Centro Universitário Univates. Lajeado, RS, Brasil
Professora do Programa de Pós-Graduação Sistemas Ambientais Sustentáveis (PPGSAS) da Univates,
Email: jamemazzarino@univates.br
Participação do autor: Todo o artigo foi realizados por ambas as partes e direito humano da água

